Орнаментальна смуга у вигляді «косички», це елемент оздоблення керамічних виробів традиційних саме для даної території (а саме Жидичинської громади), який дуже часто тут зустрічається на рештках давньої кераміки.

Кольорове вирішення.

Синій - мирне та безхмарне небо.

Зелений - символ родючості землі та добробуту.

Жовтий (в геральдиці золотий) - символ величі.

Поєднання срібного та червоного додатково підкреслює географічне розташування Жидичинської гормади, тобто на Волині.

\title{
Опис Прапора.
}

В прапорі є бажанним використанням кольорів герба, або його окремих елементів. Саме за цими критеріями був розроблений прапор Жидичинської громади.

Таке використання дасть змогу органічно поєднувати ці два символи адміністративнотеріторіальної влади у практичному використанні. Додатково прапор доповненний білою смугою, що означає річку.

Відповідно до сучасних вимог і традицій вексилології прапор населеного пункту, або громади має аналогічне (дзеркальне) зображення з обох сторін прапорного листа.

Жидичинська громада може використовувати символіку (герб, прапор) села Жидичин, як адміністративного центру даної громади.

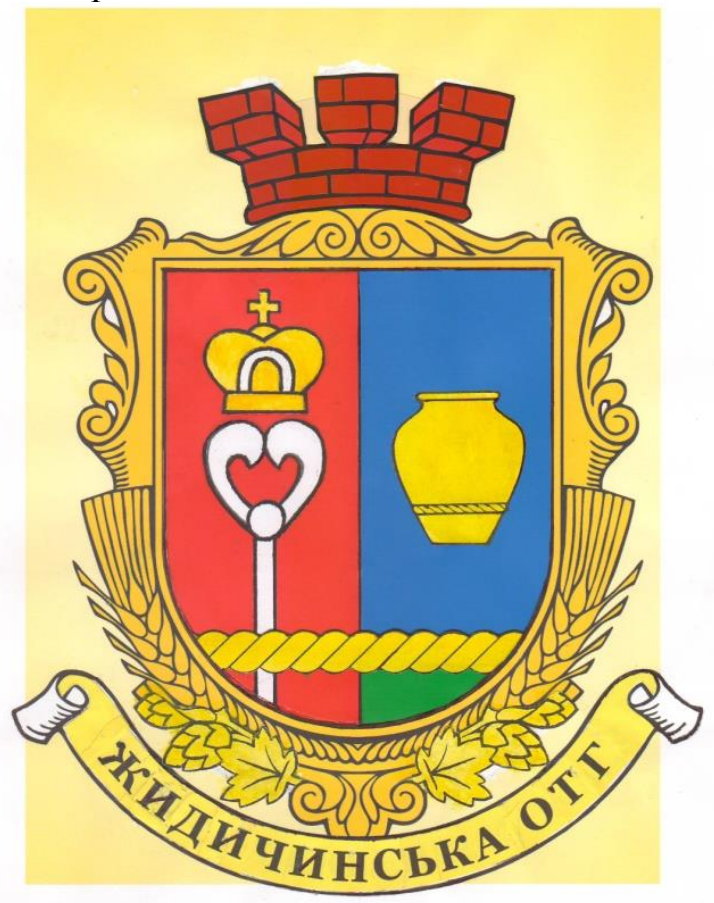

DOI: https://doi.org/10.32782/2305-9389/2020.20.03

УДК $908: 912(477.82)$

Сергій Власюк

\section{Краєзнавчий нарис з історії села Колодеже Горохівського району та навколишніх населених пунктів}

Вивчення місцевої історії є складовою історичної науки.Знання про минуле населеного пункту є одним з елементів виховання патріотизму. Актуальність теми визначається тим, що в наш час кожна людина повинна знати своє минуле, історію своєї держави і малої батьківщини, де народився $і$ виріс. Адже є такий вислів «Той, хто не знає минулого, не вартий майбутнього». Де б людина не опинилася, ї̈ батьківщина, рідний край буде завжди з нею. Всі хочуть знати історію свого села. Можливо, мої дослідження допоможуть їм у иьомуАвтор розповідає про села Горохівського району, які знаходяться навколо села Колодеже. Увага привертається до історичної топоніміки, до походження назв і окремих історичних подій, які впливали на долю иих населених пунктів. Стверджено Розмаїття місиевої топоніміки викликане горбистою місиевістю, що є причиною хутірної системи заселення села. Попри прагнення радянської влади зібрати хутори до купи, село і до сьогодні розташоване на горбах і долинах, попри невелику 
кількість жителів, більи як пів тисячі населення, займає досить велику територію. Місиева історична топоніміка збереглася у сучасних офіційних назвах вулиць села. Дослідник розповідає про становлення та розвиток поселень. Він використав дослідження краєзнавців різних років. Написання історичного нарису про село також неможливе без джерел, які містять будь-яку інформацію про населений пункт. 3 статті здійснено комплексний аналіз найрізноманітніших видів джерел: від окремих зразків археологічних знахідок до усної історії та соиіологічних досліджень, які можуть бути проведені у намі дні. Розповідь доповнена легендами та спогадами старожилів. Особлива увага приділена подіям новітньої історії. Засвідчено, щуо трагічні сторінки украӥнської історії не оминули мешканиів села.

Ключові слова: краєзнавство, топоніміка, село, Горохівський район.

Sergey Vlasyuk. Local history essay on the history of the village of Kolodezhe in the Gorokhiv district and the surrounding settlements.

The study of local history is a component of historical science. Knowledge of the past of the settlement is one of the elements of education of patriotism. The relevance of the topic is determined by the fact that in our time everyone should know their past, the history of their country and small homeland, where he was born and raised. After all, there is a saying "He who does not know the past is not worthy of the future." Wherever a person finds himself, his homeland, his native land will always be with him. Everyone wants to know the history of their village. Perhaps my research will help them in this. The author tells about the villages of Gorokhiv district, which are located around the village of Kolodezhe. Attention is drawn to historical toponymy, to the origin of names and individual historical events that influenced the fate of these settlements. Approved The diversity of local toponymy is caused by hilly terrain, which is the cause of the hamlet settlement system of the village. Despite the desire of the Soviet authorities to gather the farms in a heap, the village is still located on the hills and valleys, despite the small number of inhabitants, more than half a thousand population, occupies a fairly large area. Local historical toponymy is preserved in the modern official names of the village streets. The researcher talks about the formation and development of settlements. He used the research of local historians of different years. Writing a historical essay about the village is also impossible without sources that contain any information about the village. The article provides a comprehensive analysis of various types of sources: from individual samples of archaeological finds to oral history and sociological research that can be conducted today. The story is supplemented by legends and memories of the ancients. Special attention is paid to the events of recent history. It is proved that the tragic pages of Ukrainian history did not escape the villagers.

Key words: local lore, toponymy, village, Gorokhiv district

Назва села Колодеже походить від річки Дежа, притоки Стиру, яка на даний час висохла. В пам'ять про існування річки залишився каскад ставків на південно-східній околиці, та власне, назва села. Відповідно до джерел усної історії, селячись біля річки Дежі, жителі так і говорили: «коло Дежі» (маючи на увазі слово «коло», як синонім слова «біля»). В результаті з’явився топонім «Колодежі». Саме так жителі і називають своє село - Колодежі. ${ }^{1}$

Слушною $є$ інша думка щодо назви села. Колодежі - село при колодязях. ${ }^{2}$ Дана гіпотеза має право на існування, враховуючи зміни у назві села.

Походження назв сіл Наталин (Наталін), Ольгін та Ядвігін мають спільну легенду. Свого часу власник або орендар цих сіл, заповів як посаг, своїм трьом дочкам три хутори. Дочок звали Наталія, Ольга та Ядвіга. Звідси і Наталін, Ольгін та Ядвігін. Ім'я господаря ще не 3'ясоване ${ }^{3}$.

Будки Колодезькі були чеською колонією, де знаходилося невелике підприємство 3 випалювання вапна. Ймовірно саме «вапнярня», як її називали місцеві жителі, дала назву селу. Відомо, що «буда» і $\epsilon$ промисел 3 випалювання вапна, глини тощо. За твердженням інших старожилів, - «будки» від слова «буда» - тимчасове житло. Колодезькі ж, тому „що біля Колодеж, і це суттєво. Зовсім недалеко, на території сучасного селища Сенкевичівка, були розташовані Будки Губинські, така ж чеська колонія, де розміщувалася «цегельня» - підприємство 3 виробництва цегли.

Населенні пункти Ольгін, Ядвігін та Колодезькі Будки уже не існують.

На території села Колодеже існує ряд місцевих топонімів, що означають назви різних районів поселення.

\footnotetext{
1 Записано від Марчука Олександра Дмитровича, 1927 р.н., народився у с. Наталин Горохівського р-ну, проживає у с. Колодеже Горохівського р-ну, 2009 р.

${ }^{2}$ Білик В., Бірюліна О. Історія Жабча, Колодежа і Губина впродовж XV - XVII ст. // Минуле і сучасне Волині та Полісся: Рух опору тоталітарним і окупаційним режимам на теренах Волинської області. Горохівщина в історії України та Волині. Науковий збірник. Випуск 31. - Луцьк, 2009. - С. 107.

3 Записано від Голюк Марії Дмитрівни, 1924 - 2014., народилася у с. Наталин Горохівського р-ну, проживала у с. Колодеже Горохівського р-ну, 2009 р.
} 
«Село», саме так називається ціла вулиця, що наближена до каскаду ставків, які залишилися після протікання річки Дежа. Походження топоніму зумовлене саме існуванням на цій території першого поселення колодежців, що пізніше розвинулося у населений пункт у сучасних межах.

Місцевість «Гнилувка» розташована біля, так званого, Гнилого жолоба (западини). Попри лісову загущеність, місцевість була болотистою, мокрою, «гнилою», що і надало даному топоніму змісту.

«Залози», - топонім поселення, яке розміщувалося за заростями лози.

Існує у селі і топонім «Гаї», значення якого виходить із самої назви.

Це найдавніші топоніми на території села.

Уже у XX столітті, після прокладення через територію села дороги 3 твердим покриттям, після заселення людей вздовж неї, з'являється місцева назва цього району «Середня», або «Тристаріччя». Дорога проходила посередині села, тому назва «Середня» зрозуміла, а от топонім «Тристаріччя» виник після організації на цій території колгоспу імені 300-річчя воз'єднання України з Росією, який до речі проіснував недовго і після реорганізації був включений до складу колгоспу «Радянська Україна».

Зрозуміло значення і місцевого топоніму «Центр».

Існують інші топоніми, як-то Мартинівка, Миглясівка, що викликані прізвищами колишніх господарів земель - Мигляс, Мартинюк та інші.

Розмаїття місцевої топоніміки викликане горбистою місцевістю, що є причиною хутірної системи заселення села. Попри прагнення радянської влади зібрати хутори до купи, село і до сьогодні розташоване на горбах і долинах, попри невелику кількість жителів, більш як пів тисячі населення, займає досить велику територію. Місцева історична топоніміка збереглася у сучасних офіційних назвах вулиць села.

Питання першої письмової згадки про село неоднозначне. Вважалося, що у письмових джерелах Колодеже вперше згадується в 1594 році. ${ }^{4}$ Однак за твердженням науковців із Луцька Вікторії Білик та Олени Бірюліної перша згадка про Колодеже, що адміністративно перебувало на той час у Перемильському повіті Волинської землі, припадає на середину XV століття. «Маєток на ім'я Колодези в Перемильськом повите, с приселком его Жабком» держав Федько Хоминич, по іншому Хом'як. У $1446-1451$ pp. цей Федько був крайчим волинського удільного князя Свидригайла Ольгердовича. Його вдова вдруге вийшла заміж за Янушка, писаря господарського (1455-1488). У 1488 році Колодеже перейшло до Янушкового сина Федька Янушкевича - писаря господарського (1488-1505), маршалка Волинської землі (з 1492 року), а у 1505-1506 роках луцького старости. 23 лютого 1505 року литовський князь Олександр надав йому дарчу грамоту на користування замком, побудованим між селами Колодеже та Жабче. Помер Федько Янушкевич у 1508 році, коли перебував на посаді володимирського старости. Своїм передсмертним тестаментом він заповідав Колодеже і сусіднє Жабче луцькому кафедральному храму Іоана Богослова, найголовнішій церкві Луцької православної єпископії, що височіла на території Луцького замку. ${ }^{5}$

Таким чином, впродовж XVI-XVIII століть землі сучасного села Колодеже, сусідніх сіл Жабче і Губин Перший належали крупному церковному землевласнику - Луцькій єпархії. Фактичними власниками сіл є луцькі православні єпископи, які або здають церковні маєтки в оренду посередникам, або наставляють туди своїх урядників, або ж дарують села своїм родичам.

У 1560 році на православного єпископа Луцького і Острозького номінують Марка Васильовича Жоравницького. Станом на 1570 р. власником трьох поселень названий новий луцький єпископ - Йона Борзобагатий Красенський. У 1585 р. уведений в маєтки владицтва єпископ Кирило Терлецький.

Цікава інформація про ситуацію в Колодежах є у документі від 12 червня 1591 року. В ньому повідомляється про місцевого священика, якого звинувачували в аморальному способі життя - не виконував своїх обов’язків, пиячив, бив селян, у п’яному стані дебоширив у корчмі. Крім того,

\footnotetext{
${ }^{4}$ Історія міст і сіл Української РСР: В 26 т. Волинська область / Гол. ред. кол.: Тронько П. Т. - К.: Голов. ред. УРЕ АН УРСР, 1970. - 207c.

${ }^{5}$ Білик В., Бірюліна О. Історія Жабча, Колодежа і Губина впродовж XV - XVII ст. - С. 107.
} 
«же тот поп будучи слугою его милости епископа Терлецкого и священиком при церкви, во имению его милости в селе Колодязях» забрав багато церковних книг і 4 копи грошей, зібраних парафіянами на будівництво нової церкви і втік у невідомому напрямку. Щоправда, на суді єпископ Терлецький не став виправдовувати священика-лиходія, навіть стверджував, що відшкодував постраждалим підданим збитки. ${ }^{6}$

Не закінчилися «пригоди» села і після смерті Кирила Терлецького в 1607 році. Наступник Терлецького - єпископ Свгеній (в миру Остафій) Єло-Малинський - під час інвентаризації 1607 р. луцького владицтва стверджував, що церковні маєтки, серед яких Колодеже, по смерті його попередника були «гвалтовно» відібрані князем Сжи Чарторийським. Люди князя «побрали» у селян запаси продовольства та збіжжя, місцевих бояр і церковних підданих використовували собі на користь, незаконно збирали з них чинш. А млини, ставки, гаї й діброви «пустошили». Ще за життя о. Свгенія Єло-Малинського (помер 1620 р.) села потрапили під чергове свавілля можновладців. Королівський ротмістр князь Юрій Заславський 5 грудня 1618 р. в маєтках Жабче, Колодеже та Губин розмістив три корогви жовнірів. Здавна в Речі Посполитій існувало правило при потребі розміщати державне військо на постій в королівських, тобто в державних маєтках, але аж ніяк у приватних чи духовних. Але реально було не завжди так.

Отож Луцька уніатська капітула у квітні 1619 р. поскаржилась на князя Заславського до суду, закидаючи, що той розмістив жовнірські корогви всупереч існуючому праву.

Як свідчили скаржники, королівський ротмістр розмістив на постій три корогви: гусарську в Жабчі, піхотну в Колодежах, та козацьку у Губині. В результаті цього постою церковні піддані та Луцька єпархія зазнали великих збитків: жовніри конфіскували в селах велику кількість продовольства та худоби, змусили селян виділяти їм гроші на ремонт зброї, а ще на пиво та горілку. ${ }^{7}$

Після смерті Єло-Малинського на луцьку уніатську кафедру зійшов новий єпископ - Єремія Почаповський, який став новим власником сіл. Того ж 1620 року на українських землях була відновлена православна ієрархія.

Про тогочасну кількість жителів села Колодеже інформує тариф подимного 1629 р. Сплачувати в державну скарбницю землевласник мав 3 кожного диму (оселі) у своїх володіннях. Дідичем маєтків виступало Луцьке уніатське владицтво, яке сплачувало 384 колодеженських димів. Для волинського села цього часу коефіцієнт проживаючих в одному димі складав, в середньому, 11,8 осіб. Таким чином у першій чверті XVII століття у с. Колодеже могло мешкати близько тисячі підданих.

Православна Луцька єпископія володіла своїми маєтками, в тому числі Колодежами за управління владики Афанасія Пузини (помер 1652 р.) і його наступника о. Чаплича Шпановського. До кінця XVII ст. село все ще перебувало у власності Луцького владицтва, про що свідчить реєстр церковних маєтків на грамоті, якою польський король Ян III Собеський призначав Луцького земського писаря Дмитра Жабокрицького новим луцько-острозьким єпископом.

На початку XVIII ст. Луцька православна кафедра переходить в унію і перебуває там до середини 1790-х років, часу переходу українських земель під протекторат Російської імперії. Відтоді церковні маєтки потрапляють до приватних рук.

У середині XVII століття українське суспільство закипіло визвольною війною проти польського панування. Близькість до славетного Берестечка поклала і свій відпечаток на історії Колодеж. До наших днів дійшли перекази, що у 1651 році, після битви, багато жителів села, на прохання жителів містечка Берестечко і навколишніх сіл, переважно чоловіки, пішли, щоб поховати вбитих . Але їх по дорозі біля самого місця битви, перестрів загін шляхетських військ і цих людей було знищено.

Кожного року, після цієї події, жителі села Колодеже, йшли вшановувати пам'ять своїх односельців, які були поховані разом з козаками Хмельницького.

В першій половині XIX століття ліси і землі Колодеж належали великому землевласникумагнату Четвертинському Л.Е., який безпощадно гнобив своїх селян. В 1845 році у селі

\footnotetext{
${ }^{6}$ Білик В., Бірюліна О. Історія Жабча, Колодежа і Губина впродовж XV - XVII ст. - С. 109.

${ }^{7}$ Білик В., Бірюліна О. Історія Жабча, Колодежа і Губина впродовж XV - XVII ст. - С. 109.
} 
вибухнуло повстання проти Четвертинського. Сам він жив у Варшаві, а його маєтком управляли прикажчики. Саме вони, під виглядом різних штрафів почали незаконно захоплювати селянські землі. Тоді селяни повбивали прикажчиків графа, землі повернули собі назад. Та повернувся 3 Варшави Четвертинський із шляхетським військом і над селянами було вчинено жорстоку розправу, а землю повернуто в масив пана. ${ }^{8}$

1861 року в Росії скасували кріпосне право. Колодежці одержали по 7 десятин орної землі і по 1 десятині сіножатей, а також присадибні ділянки. На землю було складено викупні платежі, які протягом 49 років селяни мали виплатити. Кращі землі залишилися у Четвертинського, а гірші і були розділені між колишніми кріпаками.

Протягом XIX століття половина маєтностей великої власності Волині перейшла в руки росіян, шляхом конфіскацій їх у поляків, і зокрема продажу великих земельних ділянок. Численні маєтності були також розпарцельовані між чехами та німцями, котрим царський уряд зробив різні полегшення для колонізації, одночасно заборонив поселятися на Волині полякам і католикам.

Чехи почали прибувати на Волинь в 1868 році. Найбільше їх осіло в різних околицях Південної Волині. ${ }^{9}$

До сьогодні південна околиця Колодеж носить назву «колонія», що сама за себе говорить про існування у цій частині села чеських та німецьких колоністів. На підтвердження, - спогади старожилів села, які пам'ятають взірцевих господарів чехів та німців. Правда свідчення ці стосуються уже останніх років перебування на наших землях німецьких та чеських колоністів, та початок колонізації припадає саме на другу половину XIX століття.

Ймовірно, саме тоді засновується колонія Будки та заселяються колоністами хутори Ольгін, Ядвігін, Наталін.

В часи Першої світової війни особливо жорстокі бої велися на території населених пунктів в період з 20 до 28 червня 1916 року, про що свідчать оперативні карти бойових дій 11 російської армії. Через село Ольгін проходили основні напрями ударів австро-німецьких військ. Це була одна із складових славновідомого Брусиловського прориву. ${ }^{10}$

Писемну згадку про ці села ми зустрічаємо у звіті про діяльність Луцького повітового староства і відомостях про кількість сіл і населених пунктів в гмінах від 31 серпня 1920 року. Адміністративний відділ надає дані про населенні пункти Чаруківської гміни, Луцького повіту, серед яких Ольгін, Ядвігін, Наталін та Колодезькі Будки. ${ }^{11}$ У звіті подаються дані про кількість населення та національність жителів. Проживали у вищевказаних населених пунктах українці, чехи, німці та поляки.

У 30-х роках у Будках діяла школа з польською мовою викладання. Колишні учні відзначали досить високий рівень викладання у школі села Будки в порівнянні зі школою в селі Колодеже. Як пригадує жителька с. Колодеже Голюк Марія Дмитрівна: «Коли після закінчення четвертого класу у Будках ми перейшли до п'ятого у Колодеже, то дуже відрізнялися від тих хто навчався у Колодежах 3 першого класу, саме рівнем підготовки, чому завдячували будківським вчителям». ${ }^{12}$

Ще до початку II світової війни репресій зазнали німці, пізніше чехи. Поляки з українцями пережили волинську трагедію 1943 року. Ці події безумовно сприяли тому, що села зникли з лиця землі. Під час II світової війни село Наталин було спалено німцями, про що є відповідний напис на стіні пам'яті спалених сіл на Меморіалі Слави у Луцьку. Після війни, село із назвою Наталин відбудувалося, правда уже не на тій самій території, - східніше від колишніх теренів. Ольгін, Ядвігін та Колодезькі Будки були піддані забуттю. Немає про них згадки і на Меморіалі, хоча найбільш вірогідно вони розділили долю спалених українських сіл.

Події, апогеєм яких стала так звана Волинська трагедія, мають багатовікове коріння, що міцно вросло в тисячолітній грунт українсько-польських взаємин. Поразка національно-визвольної боротьби українців 1917-1920 років призвела до силового включення значної частини етнічних українських земель до складу відновленої 1918 року Речі Посполитої. Одним з найнебезпечніших

\footnotetext{
8 Записано від Марчука Олександра Дмитровича, 1927 р.н.

${ }^{9}$ М. Киричук. Волинь - земля українська. - Луцьк.: Надстир'я, 1997. - 307 с.

${ }^{10}$ Брусиловський прорив на Волині 1916 рік / Упорядник В. Данилюк. - Луцьк.: Останній солдат, 2006. - 8 с.

11 Державний Архів Волинської Області. - Ф. 36. - Оп. 1. - Спр.39. - Арк. 4.

12 Записано від Голюк Марії Дмитрівни, 1924 р. н.
} 
та вибухових заходів, здійснюваних польським урядом стосовно Західної України в 19201930 роках, стало масове заселення польськими селянами і без того перенаселених українських воєводств.

Загалом у сільську місцевість протягом 20 років було переселено 200 тис. етнічних поляків, до них слід долучити ще 100 тис. поляків, які оселилися в містах і працювали державними чиновниками та службовцями правоохоронних органів. ${ }^{13}$

Не було винятком і село Колодежі, Чаруківської гміни Луцького повіту. На той час у селі нараховувалося більше 300 родин. Поляки у Колодежах розселилися на південно-східній околиці села.

Якщо за керівництва Йосипа Пілсудського дискримінація українського населення була напівприкритою, то з приходом до влади Ридза Сьмігли стала тотальною, відкритою. Настали обмеження навіть на отримання середньої освіти, а набути вищу освіту, залишаючись православного віросповідання, стало неможливим. Колишній житель села Колодежі, Володимир Ягенський пригадує: «У школі я не мав права звернутися до вчителя рідною мовою, бо вчитель зразу починав кричати: «Я єнзик свіньські не розумем. Мув до мнє в єнзику шляхетським» ${ }^{14}$.

I так було по всіх українських землях. Така політика уряду викликала адекватну реакцію у пригнобленого українського населення краю, а особливо в української молоді. Саме серед молоді щороку зростала популярність радикальних націоналістичних організацій (насамперед ОУН), котрі проповідували військові методи боротьби з польським окупаційним режимом.

Напад Німеччини та СРСР на Польщу у вересні 1939-го і зникнення Речі Посполитої 3 політичної карти світу було сприйнято значною частиною політично активного українського громадянства як справедливе покарання полякам за їхню виразну антиукраїнську довоєнну політику. Спираючись на подібні настрої українського народу, як нацисти, так і більшовики вже 3 кінця 1939 року проводили лінію на «загравання» з українським населенням окупованої польської держави. Усвідомлюючи, що це викличе гостро негативну реакцію поляків, нацисти навмисно всяко рекламували привілейоване становище українців. Подібне діялося і у новоприєднаних областях Радянської України. Українізація освіти, культури, адмінапарату, націоналізація земель багатих польських власників та депортація сотень тисяч поляків у Сибір створювала ілюзію встановлення "української влади" на колишніх «східних кресах» Речі Посполитої .

У червні 41-го два тирани зійшлися у кровопролитній війні. 3 приходом фашистів у Сенкевичівський район, до складу якого входило село Колодежі, прибуло два німці наводити свої порядки. Одного з них звали Ампель. Розпочали вони з організації поліції та призначення старост із населення української національності. Німецька пропаганда, пообіцявши самостійність Україні, від більшості українців отримала підтримку. Багато українських хлопців добровільно пішли у поліцію. 3 Колодеж пішло п'ять хлопців з бідних родин. Полякам, як гордовитій нації, дуже не подобалось, що ними будуть керувати представники «нижчої раси».

Від старостів німці вимагали організації постачання продукції харчування з акцентом на м'ясну. Селяни, уже привчені сталінським режимом до майже безоплатного вилучення своєї продукції, віддавали і німцям. Весною 1943 року залишилось у господарствах по одній корові, свині, та вівці (якщо вівці утримували) і селяни відмовилися віддавати останнє. Німці поставили вимогу перед поліцією, щоб насильно забирали худобу. Поліцаї не спішили виконувати це завдання, і однієї ночі уся поліція із зброєю розійшлась по домівках. У Колодежах німці створили новий склад поліції але уже із поляків ${ }^{15}$.

Створення польського (за національною належністю більшості працівників) адмінапарату та формування 3 місцевих поляків батальйонів допоміжної поліції (замість української допоміжної поліції, яка в березні 1943 року перейшла до УПА) дало змогу керівництву Армії Крайової сподіватися на швидке захоплення влади в краї у разі ослаблення Німеччини. На жаль, упродовж усієї війни лідери польського руху опору так і не відмовилися від великодержавних претензій на

\footnotetext{
${ }^{13}$ Патриляк І. Волинь - 1943 // Досвітня зоря. - 2003. - № 15. - С. 8.

${ }^{14}$ Ягенський В. До помсти кликала жорстокість // Волинь. - 2003. - № 88. - С. 3.

${ }^{15}$ Ягенський В. До помсти кликала жорстокість. - С. 3.
} 
українські етнічні землі. На нашу думку, саме така позиція поляків, а не радикальний націоналізм ОУН-бандеівців та керованої ними УПА стала головною причиною проведення повстанцями збройних акцій проти польських колоній та сіл у 1943- 1944 роках.

Десь у травні 43-го року в неділю рано у Колодежі приїхав німець Ампель 3 новою поліцією. Родини колишніх поліцаїв розстріляли, а будівлі і трупи спалили. Самі колишні поліцаї, зауваживши нову поліцію, втекли 3 дому і здебільшого залишилися живими. Це була перша, вибіркова, якщо так можна сказати, екзекуція. Невдовзі була здійснена і широкомасштабна. Людей із с. Красний Сад тодішнього Сенкевичівського району оточили, загнали у три добротних клуні і живцем спалили. Через кілька тижнів після екзекуції над родинами колишніх поліцаїв останні зібралися й однієї ночі знищили родини поліцаїв - поляків.

На той час, навіть і після масового вбивства українців у с. Красний Сад, в українців ще не виникла люта ненависть 3 ознаками помсти до поляків взагалі, але з'явилася настороженість. Селяни почали будувати криївки та озброюватись.

Населення було настороженим, а 3 утворенням Української Повстанської Армії організованішим. У Колодежах були цілодобові чергування. Місця для чергування вибиралися так, щоб поданий звуковий сигнал (у рейку) в будь-яку погоду почув ближчий черговий.

Майже систематично здійснюваний терор щодо українського населення району викликав озлоблення в українців і найактивніші 3 них ночами, здійснювали терор над польськими родинами, але вибірково, над т. зв. осадниками та колишніми польськими активістами. Звичайно, тут не можна категорично відкидати й помсти на побутовому грунті. У Колодежах події розгорталися не менш трагічно. Не отримуючи від населення продовольства, Ампель вирішив налагодити постачання зерна для Німеччини. Розпорядився завезти в наше село модерну на той час молотилку для обмолоту збіжжя. Одного ранку у Колодежі приїхали поліцаї з молотилкою, вибрали вигідне для себе місце і почали звозити з полів скошене збіжжя і обмолочувати.

Першого дня “молотильники” вели себе спокійно, займалися лише обмолотом. Наступного дня, очевидно, для розваги, частина «золотильників» вирішила виїхати на «полювання». Виїхали на дорогу, що вела через с. Жабче до містечка Боремель Демидівського району Рівненської області. Повільно їдучи вантажним автомобілем, стріляли по сторонах. Наступного дня виїзд на «полювання» повторили. 3 дороги не звертали, та 3 автомобіля не висідали. Пострілювали по сторонах продовживши маршрут аж за містечко Боремель, і зупинилися на крутому березі р.Стир. Цього дня «вполювали» (убили) три людини і кількох поранили.

3 настанням третьої ночі перебування «золотильників» на них напали повстанці, й непрошені гості були змушені втекти до Сенкевичівки. Через кілька днів повстанці напали й на Сенкевичівку, і ці два німці і усі їхні прислужники (поляки) з родинами були змушені втекти до м. Луцька. Відтоді й аж до ранньої весни 1944 року, тобто до прибуття відступаючих німецьких фронтовиків, Сенкевичівський район перебував під контролем УПА. Одного дня колодежці побачили кружляння над своїм селом кількох двомоторних літаків і почули два вибухи. Як пізніше виявилось, на територію школи була скинута фугасна, а церкви - осколкова бомби. Мабуть, Ампель зі своїми прислужниками вважав, що в селі перебуває велика кількість повстанців і попросив армійської підмоги. У цей день було вбито 93 особи, серед них і одиноку 90-річну німку (остання відмовилась у 1940-ому році виїхати до Німеччини) та спалено третину села.

Однак, ведучи мову про польсько-українське протистояння, не можна забувати про ще одну зацікавлену та могутню сторону конфлікту, яка, подібно до нацистів, сприяла посиленню українсько-польської ворожнечі. Йдеться, безумовно, про московських «режисерів», котрі 3 Кремля всіма силами та засобами провокували й розпалювали конфлікт.

30 квітня 1944 року село було звільнено від німецької окупації. Відкривалася жахлива картина. Ще восени 1943 село було майже повністю зрівняне із землею. Із 725 селянських господарств залишилося лише 25 хат. Уже з перших днів після звільнення було встановлено радянську владу - організовано сільську раду. Першим повоєнним головою сільської ради був призначений Кардаш Федір Іларіонович, секретарем Плисюк Дмитро Степанович. Дуже мало було людей тоді у селі, переважно жінки. Чоловіки ще воювали, багато загинуло під час окупації.

Уже в перші місяці після визволення у селі відновлюється діяльність школи. За наказом радянського уряду, в цей час, почали відправляти на роботу, вчителів у західну Україну з більш 
лояльнішої до більшовицької влади - східної. 10 лютого 1945 року за таким наказом, у Колодежі прибули дві молоді вчительки 3 Вінницької області Шибінська Олександра Семенівна та Максимчук Надія Трохимівна. На той час у селі вже працювали вихідці зі сходу, які появились тут ще раніше - наприкінці 1944 року: Римич Доміцеліна Йосипівна та директор школи Таранчук Олександр. Крім них у школі працювали місцеві вчителі Абрамович Валер'ян Петрович, Пшенюк Слизар Степанович, Стецюк Захар Антонович, Сущук Микита Якович. Педколектив жив дружно. Школи, як такої, не було, - був будинок із трьома класними кімнатами і все. Дітей не могли розмістити у цій школі, приходилось проводити заняття у сільських хатах. Один клас був у хаті Ковальчука Степана, другий у хаті вивезеної сімї Фурманюка Петра. Підручників не було, користувалися старими і тих було обмаль. Умови для праці були надзвичайно важкі, учні ж були чемні, ввічливі і добродушні. Усі вони тягнулися до навчання і вчились дуже добре, незважаючи на те, що було багато переростків. У 6, 7 класах навчалися 16-17 літні. Десь у 1946-47 роках, силами вчителів, учнів та жителів села, було добудовано до старої школи, ще чотири кімнати.

3 початком нового навчального року у 1945 році у Колодезьку школу на роботу приїхала молода дівчина Кабашна Галина. Працювала вона старшою піонервожатою. У колективі була наймолодша. Для того, щоб усвідомити ті умови в яких доводилося працювати першим післявоєнним вчителям, у відновленій школі, слід звернутися до історичної обстановки на Західній Україні в другій половині $40-$ х років. Тоталітарний радянський режим, відновивши свою владу на західноукраїнських землях, першочерговим своїм завданням вважав уже ніколи ії не втратити.

Замішана на крові, більшовицька влада, викликала шалений опір у тих, хто бажав будувати своє життя на своїй землі. Друга половина 40-х років - період активного опору ОУН-УПА. Свідомі українці не погоджувалися 3 існуючим станом речей. Їх мета булав встановлення самостійної України, тому боротьба 3 радянською владою була їх першочерговою задачею. Боротьба ні на життя, а на смерть. Саме в епіцентрі такого політичного горнила і приходилось працювати педагогам у перші повоєнні роки на Західній Україні. Ставши заручниками історичної обстановки, вчителі відповідали за ті кривди та політику, які проводила сталінська адміністрація на теренах всієї радянської імперії. Відповідали найдорожчим - своїм життям. Не можна не зважати, що крім УПА на волинських теренах, у роки війни та у перші післявоєнні, діяли різні угрупування: «партизанка», звичайні бандитські групи, провокаційні групи НКВС, жертви яких теж списували на УПА. Саме тому побутові та чисто професійні проблеми, на фоні такої обстановки видавалися несуттєвими. Директор школи не мав спокійної ночі, і навіть на уроки ходив з гвинтівкою.

Молоде дівча Галина Кабашна щиро прийняла у своє, ще дитяче серце, ідеї комуністичної організації. Вона весь час знаходилася серед учнів, проводила різні ігри, читала дитячі книжки. Настав час, коли треба було залучати дітей до вступу у піонери. Зробили збори, Галина виступила коротко, розповіла про цю дитячу організацію і запропонувала, щоб діти вступали у піонери. Реакції не було, всі мовчали. Пройшов деякий час, Галина стояла на своєму, запрошувала, роз'яснювала, але марна справа.

В травневу ніч 1946 року Галини Кабашної не стало. Вона була вбита розривною кулею, на подвір'ї біля хати, де вона жила.

Ця трагедія - найстрашніший випадок в історії села, коли за ідеологічні штампи комуністичної держави в жертву було принесено життя вчителя, педагога. Протягом усього існування Радянського Союзу вчителі повинні були дублювати політичні настрої «країни Рад». Той, хто йшов в розріз з ідеологією існуючої влади, був усунутий чи знищений, фізично чи морально. ${ }^{16}$

70-80 роки XX століття виявилися найбільш динамічнішими у розвитку села Колодеже. Інфраструктура села набувала сучасних рис. Структура колгоспу складалася з трьох відділків, на території яких знаходились по одній тваринницькій фермі великої рогатої худоби, крім того, у 1 відділку діяла свиноферма. У селі було збудовано машинно-тракторний парк, який забезпечував

16 Записано від Крисюк Людмили Сергіӥвни, 1936 р.н., народилася в с. Колодеже, Горохівського р-ну, проживає у с. Колодеже Горохівського р-ну, 2009 р. 
господарство технічним забезпеченням усіх сільськогосподарських робіт. Для забезпечення боротьби з пожежами діяло колгоспне пожежне депо. Головою колгоспу був призначений авторитетний керівник Шевчук Сергій Федорович. Секретарем комуністичної партійної організації працював Галяс Володимир Миколайович.

Органом місцевої влади була сільська рада, яку очолював Марчук А. П., Мигляс П. М., Марчук (Галяс) Т. В. Культурно-просвітницьку роботу забезпечував новозбудований будинок культури 3 залом на 150 посадкових місць. Завідувачем клубу працювала Мигляс Лариса Кузьмівна. Медичне обслуговування населення села здійснювали працівники сільського медичного пункту.

У 1980 році у селі була збудоване нове приміщення восьмирічної школи на 320 учнівських місць. Директором школи працювала Мигляс Людмила Сергіївна, заступником директора Жук Надія Лукашівна.

70-80 роки виявилися найбільш успішнішими у розвитку села. Колгосп «Радянська Україна» не належав до самих передових у районі, однак за основними показниками розвитку господарювання завжди входив до першої десятки. Це був період стабільного розвитку, коли кожен колгоспник мав роботу і нехай невисоку, але регулярну заробітну плату. Подальша державна політика Радянського Союзу, а пізніше незалежної України привела до руйнації встановленого устрою на селі, що привело до негативних наслідків.

Нова економічна ситуація в кінці 80 -х, на початку 90 -х років привела до занепаду колгоспного життя, а пізніше і до його ліквідації. Ще декілька років на території села діяли селянська спілка «Дежа» та сільськогосподарське підприємство «Колодежі» та і вони виявилися недовговічними в умовах реформаторських починань української влади.

22 травня 2001 року відкрито новий Святомиколаївський храм (УПЦ КП).

В березні 2005 року, рішенням сесії сільської ради було затверджено найменування вулиць, що мають давнє історичне походження: Гаї, Залози, Гнилувка, а також Центральна, Шкільна, Набережна.

\section{Джерела та література:}

1. Білик В., Бірюліна О. Історія Жабча, Колодежа і Губина впродовж XV - XVII ст. // Минуле і сучасне Волині та Полісся: Рух опору тоталітарним і окупаційним режимам на теренах Волинської області. Горохівщина в історії України та Волині. Науковий збірник. Випуск 31. - Луцьк, 2009. - С. 107.

2. Брусиловський прорив на Волині 1916 рік / Упорядник В. Данилюк. - Луцьк.: Останній солдат, 2006. $8 \mathrm{c}$.

3. Державний Архів Волинської Області. - Ф.36. - Оп.1. - Спр.39. - Арк.4; ДАВО, Ф. Р - 6. - Оп.4. Спр.63. - Арк.50-58.

4. Історія міст і сіл Української РСР: В 26 т. Волинська область / Гол. ред. кол.: Тронько П. Т. - К.: Голов. ред. УРЕ АН УРСР, 1970. - 207c.

5. Киричук М. Волинь - земля українська. - Луцьк.: Надстир'я, 1997. - 307 с.

6. Патриляк І. Волинь - 1943 // Досвітня зоря. - 2003. - №15. - С. 8.

7. Полонська-Василенко Н.. Історія України .Т. ІІ. - К.: Либідь, 1992. - 430 с.

8. Турченко Ф. Новітня історія України. Част.1. - К.: Генеза, 2002. - 234 с.

9. Чучман Л. Колодежам - 400 років // Горохівський вісник. -1994 . -11 лютого. - С. 3.

10. Ягенський В. До помсти кликала жорстокість // Волинь. - 2003. - № 88. - С.3. 